\title{
Development of Fourier transform mid-infrared calibrations to predict acetone, $\beta$-hydroxybutyrate, and citrate contents in bovine milk through a European dairy network
}

\author{
C. Grelet, ${ }^{* 1}$ C. Bastin, $\dagger^{1}$ M. Gelé, $\ddagger$ J.-B. Davière,§ M. Johan,§ A. Werner,\# R. Reding,Il J. A. Fernandez Pierna, * \\ F. G. Colinet, $†$ P. Dardenne, ${ }^{*}$ N. Gengler, $\dagger$ H. Soyeurt, $\dagger$ and F. Dehareng*² \\ *Walloon Agricultural Research Center (CRA-W), Valorization of Agricultural Products Department, 24 Chaussée de Namur, 5030 Gembloux, \\ Belgium \\ †University of Liège, Gembloux Agro-Bio Tech, Agriculture, Bio-engineering and Chemistry Department, 2 Passage des Déportés, \\ 5030 Gembloux, Belgium \\ \#French Livestock Institute (IDELE), 9 rue André Brouard, CS 70510, 49105 Angers cedex 02, France \\ $\S$ Clasel, 141 Boulevard des Loges, 53942 Saint Berthevin, France \\ \#Landeskontrollverband (LKV) Baden Württemberg, Heinrich-Baumann Str. 1-3, 70190 Stuttgart, Germany \\ \|Convis S.C., 4 Zone Artisanale et Commerciale, 9085 Ettelbruck, Luxembourg
}

\section{ABSTRACT}

To manage negative energy balance and ketosis in dairy farms, rapid and cost-effective detection is needed. Among the milk biomarkers that could be useful for this purpose, acetone and $\beta$-hydroxybutyrate (BHB) have been proved as molecules of interest regarding ketosis and citrate was recently identified as an early indicator of negative energy balance. Because Fourier transform mid-infrared spectrometry can provide rapid and costeffective predictions of milk composition, the objective of this study was to evaluate the ability of this technology to predict these biomarkers in milk. Milk samples were collected in commercial and experimental farms in Luxembourg, France, and Germany. Acetone, BHB, and citrate contents were determined by flow injection analysis. Milk mid-infrared spectra were recorded and standardized for all samples. After edits, a total of 548 samples were used in the calibration and validation data sets for acetone, 558 for BHB, and 506 for citrate. Acetone content ranged from 0.020 to $3.355 \mathrm{mmol} / \mathrm{L}$ with an average of $0.103 \mathrm{mmol} / \mathrm{L}$; BHB content ranged from 0.045 to $1.596 \mathrm{mmol} / \mathrm{L}$ with an average of 0.215 $\mathrm{mmol} / \mathrm{L}$; and citrate content ranged from 3.88 to 16.12 $\mathrm{mmol} / \mathrm{L}$ with an average of $9.04 \mathrm{mmol} / \mathrm{L}$. Acetone and BHB contents were log-transformed and a part of the samples with low values was randomly excluded to approach a normal distribution. The 3 edited data sets were then randomly divided into a calibration data set (3/4 of the samples) and a validation data set $(1 / 4$ of the samples). Prediction equations were developed

Received October 2, 2015.

Accepted February 12, 2016.

${ }^{1}$ These authors contributed equally.

${ }^{2}$ Corresponding author: f.dehareng@cra.wallonie.be using partial least square regression. The coefficient of determination $\left(\mathrm{R}^{2}\right)$ of cross-validation was 0.73 for acetone, 0.71 for $\mathrm{BHB}$, and 0.90 for citrate with root mean square error of $0.248,0.109$, and $0.70 \mathrm{mmol} / \mathrm{L}$, respectively. Finally, the external validation was performed and $\mathrm{R}^{2}$ obtained were 0.67 for acetone, 0.63 for $\mathrm{BHB}$, and 0.86 for citrate, with respective root mean square error of validation of $0.196,0.083$, and 0.76 $\mathrm{mmol} / \mathrm{L}$. Although the practical usefulness of the equations developed should be further verified with other field data, results from this study demonstrated the potential of Fourier transform mid-infrared spectrometry to predict citrate content with good accuracy and to supply indicative contents of BHB and acetone in milk, thereby providing rapid and cost-effective tools to manage ketosis and negative energy balance in dairy farms. Key words: Fourier transform mid-infrared spectrometry, milk, acetone, $\beta$-hydroxybutyrate, citrate

\section{INTRODUCTION}

Fourier transform mid-infrared (FT-MIR) spectrometry is a method of choice to perform composition and quality controls during routine liquid milk testing. It allows a fast and nondestructive quantification of milk chemical properties to avoid reference methods, which are usually tedious, expensive, and time consuming. Today, FT-MIR spectrometry is used worldwide to predict contents of fat, protein, urea, and lactose in official milk-recording schemes and milk payment systems. In addition, several studies undertaken over the last decade demonstrated the potential of FT-MIR to predict detailed milk composition (De Marchi et al., 2014), for example, fatty acid profile (Rutten et al., 2009; Soyeurt et al., 2011), protein composition (Bonfatti et al., 2011), lactoferrin (Soyeurt et al., 2012), 
Table 1. Overview of calibration and validation statistics from various studies aiming at predicting acetone content in milk by Fourier transform mid-infrared spectrometry; reference method for quantifying acetone, number of samples used, root mean square error (RMSE), standard error of cross-validation (SECV), and $\mathrm{R}^{2}$ are presented ${ }^{1}$

\begin{tabular}{|c|c|c|c|c|c|c|c|c|c|c|}
\hline Reference & Reference method & \multicolumn{3}{|c|}{ Calibration } & \multicolumn{3}{|c|}{ Cross validation } & \multicolumn{3}{|c|}{ External validation } \\
\hline Hansen, 1999 & Vanillin test & 302 & - & - & - & 0.240 & 0.80 & 58 & 0.270 & 0.81 \\
\hline de Roos et al., 2007 & Continuous flow analyzer & 1,063 & - & - & 0.184 & - & 0.72 & - & - & - \\
\hline Hanuš et al., 2011 & $\begin{array}{l}\text { Microdiffusion } \\
\text { photometric }\end{array}$ & 14 & - & 0.65 & - & - & - & - & - & - \\
\hline
\end{tabular}

${ }^{1} \mathrm{RMSE}$ and SECV are expressed in $\mathrm{mmol} / \mathrm{L}$.

minerals (Soyeurt et al., 2009), technological properties of milk (e.g., coagulation properties, curd firmness, and cheese yield; De Marchi et al., 2014), and the physiological state of the cow (e.g., methane emissions; Vanlierde et al., 2015), pregnancy status (Lainé et al., 2014), body energy status (McParland et al., 2011), energy intake, and efficiency (McParland et al., 2014). Hence the analysis of milk by FT-MIR spectrometry offers the opportunity to record a whole range of new phenotypes to develop tools enabling profitability and sustainability of the dairy sector (Gengler et al., 2015) as well as genetic and genomic evaluations (Gengler et al., 2016).

Over the range of traits potentially predictable by FT-MIR spectrometry, biomarkers of negative energy balance state and ketosis are of primary importance for optimized fertility, health, and welfare of high-yielding dairy cows. The extent and the duration of the postpartum negative energy balance have been identified as one of the major factor influencing fertility and health of dairy cows (Collard et al., 2000; Butler, 2003). BjerreHarpøth et al. (2012) mentioned that citrate content, among various metabolites measured in milk, had the greatest response during a period of negative energy balance. Baticz et al. (2002) concluded that content of citrate should be measured by easy and automated method such as FT-MIR technology to evaluate the energy status of cows. Furthermore, (sub)clinical ketosis, caused by excessive body fat mobilization due to severe negative energy balance, is one of the most frequent production diseases, with a prevalence ranging from 7 to $43 \%$ in the first 2 mo of lactation (Suthar et al., 2013). Ketosis negatively affects milk yield and reproductive performances; it also increases the risk of subsequent diseases such as displaced abomasum (Duffield, 2000). The major ketone bodies in milk (i.e., $\mathrm{BHB}$, acetone, and acetoacetate) are the most common indicators of ketosis in milk (Enjalbert et al., 2001).
Previous studies attempted to predict acetone content in milk by using FT-MIR spectrometry. As shown in Table 1, these studies differ in the reference method used to quantify acetone content but also in the number of samples used. Coefficients of determination of calibration and of cross-validation ranged from 0.39 to 0.80 (Table 1). Except Hansen (1999), these authors did not perform external validation. de Roos et al. (2007) investigated the prediction of BHB by FT-MIR spectrometry. Using 1,069 samples, they obtained a $\mathrm{R}^{2}$ of cross-validation of 0.63 and a standard error of crossvalidation of $0.065 \mathrm{mmol} / \mathrm{L}$. Using FT-MIR predictions of acetone and BHB contents in milk, van Knegsel et al. (2010) and van der Drift et al. (2012) investigated the opportunity of such predictions for the detection of ketosis in dairy cows. To our knowledge, no study had reported calibration statistics for the prediction of citrate contents in milk by FT-MIR spectrometry although FT-MIR predictions of citrate have been used in the work of Bjerre-Harpøth et al. (2012).

The objectives of this study were (1) to build calibrations predicting acetone and BHB contents in milk and to evaluate their usefulness for use on field with an external validation data set and (2) to assess the potential of FT-MIR spectrometry to predict citrate content in milk. The first novelty of this work lies in the combination of data from cows of different breeds collected in different countries and production systems as well as in the combination of spectral data from several apparatus of different brands. The merging of spectral data relies on the FT-MIR standardization procedure developed by Grelet et al. (2015). This method brings possible the collation of the data set, thereby increasing the robustness of calibrations and the use of the developed calibrations by all standardized instruments. The second novelty of this work is to provide a detailed external validation procedure to assess the robustness of the calibrations developed. 
Table 2. Characteristics of the 4 sample sources

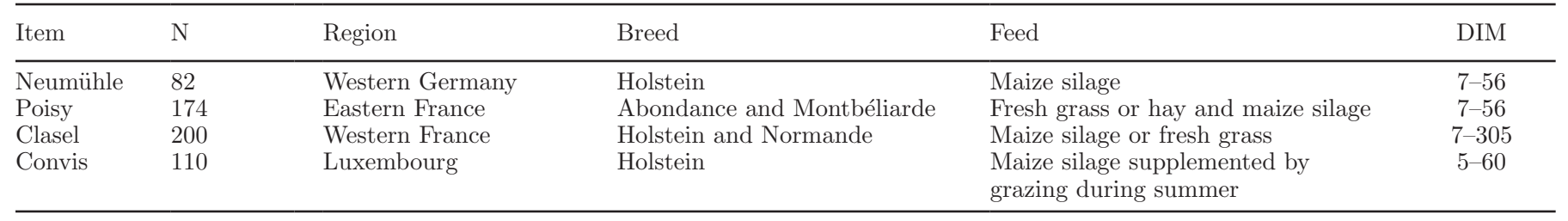

\section{MATERIALS AND METHODS}

\section{Sampling}

The sampling was undertaken from August 2013 to June 2014. Milk samples were collected by 4 organizations from 3 countries in both research and commercial farms (Table 2). After removing subsets of samples thawed during transport or poorly preserved and subsets of samples showing issues during spectra acquisition or during reference analysis, the initial data set included 566 samples. A total of 256 milk samples originated from 2 experimental farms from cows at 7 to $56 \mathrm{~d}$ postcalving to focus on the postpartum period when cows are at the greatest risk of metabolic disorders due to negative energy balance. Eighty-two samples were collected in Neumühle experimental farm (Germany) from Holstein cows fed mainly with maize silage. A total of 174 samples were recorded in the Poisy experimental farm (France) from Abondance and Montbéliarde cows fed with fresh grass during summer or with hay and maize during winter season. In addition, 310 samples were collected in commercial farms by Milk Recording Organizations. Several 200 samples were collected by Clasel in the west of France, from Holstein and Normande cows fed mainly with maize silage during winter and grass during summer. Samples were selected at the laboratory based on milk parameters known to be related to ketosis status such as fat to protein ratio. In Luxembourg, 110 samples were collected by Convis s.c. from Holstein cows fed mainly with maize silage supplemented by grazing during summer. For all cows, milk samples were collected by using sampling systems approved by ICAR. Morning and evening samples were pooled to obtain daily milk and 2 identical samples were generated to be analyzed by FT-MIR and reference analysis.

\section{Fourier Transform Mid-Infrared Analysis}

All samples were analyzed fresh by local milk recording organizations. A total of 10 different instruments, located in 5 laboratories, were used in the study. The instruments were located in Germany (6), France (2), and Belgium (2). Table 3 provides the technical information related to the instruments used in this study. To combine them into a common database, the spectra recorded from all these instruments were standardized into a common format using the piece-wise direct standardization method and the protocol developed within the OptiMIR project (Grelet et al., 2015). For each spectrum, the standardized Mahalanobis distance (GH) was calculated and no spectrum was considered as an outlier.

\section{Reference Analysis}

The samples dedicated to the reference analysis were sent to the Walloon Agricultural Research Center (CRAW, Gembloux, Belgium) to be analyzed. Samples from Germany and France were frozen before being sent, and the samples from Luxembourg were preserved with bronopol at $0.01 \%$ and analyzed fresh. The BHB and acetone content in milk were analyzed by a continuous flow analyzer (Scan ++ , Skalar, Breda, the Netherlands) using the procedure described by de Roos et al. (2007). Citrate was also analyzed with continuous flow analyzer, based on enzyme-catalyzed reaction. Citrate is converted into oxaloacetate and acetate, catalyzed by citrate lyase, and oxaloacetate decarboxylases into pyruvate. Oxaloacetate and pyruvate are then reduced by nicotinamide dinucleotide (NADH) into malate and lactate, which are catalyzed by malate and lactase dehydrogenase. Decrease of NADH is stoichiometric with

Table 3. Characteristics of the Fourier transform mid-infrared instruments used in the study

\begin{tabular}{|c|c|c|c|c|c|}
\hline Brand & Type & $\begin{array}{l}\text { Number of } \\
\text { instruments }\end{array}$ & $\begin{array}{l}\text { Frequency reported by } \\
\text { constructors }\left(\mathrm{cm}^{-1}\right)\end{array}$ & $\begin{array}{c}\text { Number of } \\
\text { wavenumbers }\end{array}$ & Resolution \\
\hline Foss Electric A/S (Denmark) & FT 6000 & 3 & 926 to 5,010 & 1,060 & Unknown \\
\hline Foss Electric A/S (Denmark) & $\mathrm{FT}+$ & 2 & 926 to 5,010 & 1,060 & Unknown \\
\hline Bentley (United States) & FTS & 5 & 649 to 3,999 & 899 & $8 \mathrm{~cm}^{-1}$ \\
\hline
\end{tabular}

${ }^{1}$ Number of wavenumbers is the total data points numbers of the raw spectra before interpolation and area selection. 
citrate content, and the remaining NADH is measured by optical density at $340 \mathrm{~nm}$. Ranges of analysis of the continuous flow analyzer provided by the supplier are 0.02 to $1 \mathrm{mmol} / \mathrm{L}$ for acetone, 0.04 to $2 \mathrm{mmol} / \mathrm{L}$ for $\mathrm{BHB}$, and 0.03 to $24 \mathrm{mmol} / \mathrm{L}$ for citrate; otherwise values are estimated by extrapolation. All samples were analyzed twice, and samples with variation higher than $5 \%$ were re-analyzed. Standard error of laboratory, which is the repeatability of the reference method, was calculated. From the 566 samples, for each component the samples with missing value or with value under the lower limit of detection of the respective analysis were removed, leading to 558, 548, and 506 samples, respectively, for $\mathrm{BHB}$, acetone, and citrate data set.

\section{Calibration and Validation}

Preliminary statistics indicated that acetone and BHB values were not normally distributed, with a higher proportion of low values. When performing calibration, this type of distribution gives too much weight to the low values, leading to a low accuracy in predicting high values. Therefore, editing of data was needed to use a more balanced data set between low and high values. Several samples in the cloud of low values were randomly removed to obtain a reduced data set covering the same range of values, but giving less weight on low values. Visual inspection of the data indicated that this large number of low values was situated between 0.025 and $0.085 \mathrm{mmol} / \mathrm{L}$ for acetone. Hence, $66 \%$ of these data was randomly removed. After this edit, the number of samples for acetone was 224 . The same process was used for BHB values for which the large number of samples with low values was situated between 0.100 and $0.250 \mathrm{mmol} / \mathrm{L}$, thereby bringing the number of data to 434. A logarithmic (10) transformation was then applied on both acetone and BHB reference values to approach a normal distribution. Figure 1 shows the distribution of the acetone data set before and after the logarithmic transformation and after removing randomly a part of the low values. The citrate reference data set was normally distributed, and it was therefore not further edited. For all data sets, a quarter of the data was randomly excluded in the calibration process to be used as an external validation.

As pretreatment of FT-MIR spectra, a first derivative was used with a gap of 5 wavenumbers, associated with an autoscale preprocess only for acetone and BHB. The spectral area selected were 968.1 to $1,577.5$ $\mathrm{cm}^{-1}, 1,731.8$ to $1,762.6 \mathrm{~cm}^{-1}, 1,781.9$ to $1,808.9 \mathrm{~cm}^{-1}$, and $2,831.0$ to $2,966.0 \mathrm{~cm}^{-1}$. Detailed evaluation of the spectra based on previous knowledge has permitted the selection of those wavenumber bands. Noisy areas induced by water were removed. And to bring the models as robust as possible, only the wavenumbers with a spectral response highly correlated between different instruments when analyzing common samples were used. Calibrations were done using partial least square (PLS) regression. Cross-validations were performed on the calibration data sets using 10 subsets randomly constituted, and samples with residuals higher than 2.5 times the SD of the global residuals were considered as outliers (Rousseeuw et al., 2006). Models were then applied on the external validation data sets. Both cross-validation and validation results were expressed in terms of $\mathrm{R}^{2}$, root mean square error (RMSE), and ratio performance/deviation (RPD). The goal of the RPD criterion is to show simultaneously the accuracy of predictions and the global variability of the reference values (Williams and Sobering, 1993). The RPD is defined as the ratio SD/RMSE as RMSE can be the one calculated in cross-validation or the one of a validation set. When the RPD is between 1.5 and 2, the model

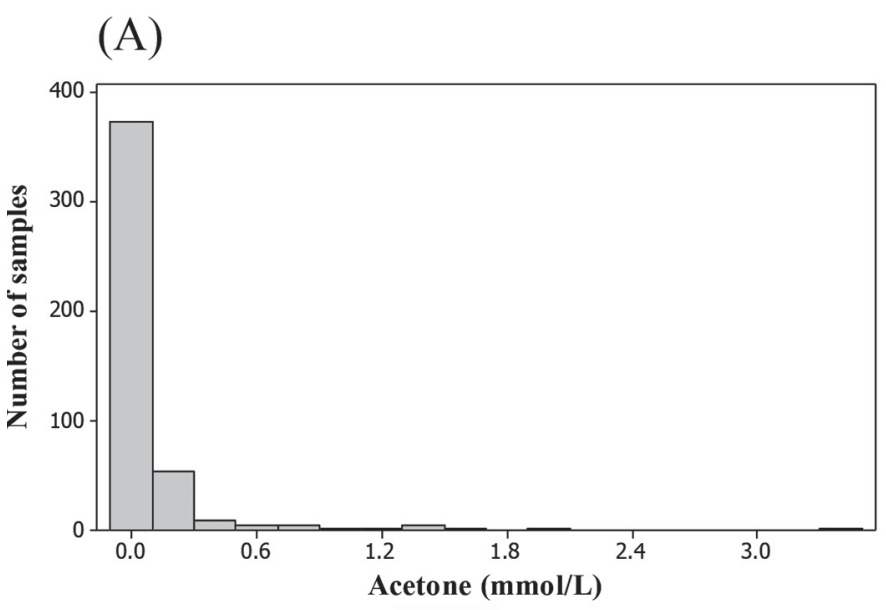

(B)

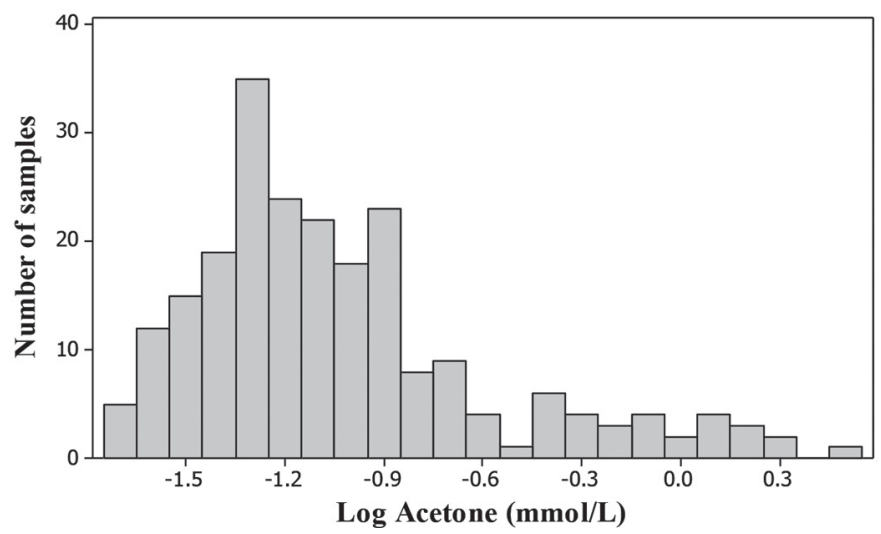

Figure 1. Effect of editing the acetone data set on the distribution of values: (A) Original data set after preliminary editing $(\mathrm{n}=548)$, (B) data set after logarithmic transformation and removing randomly low values $(\mathrm{n}=224)$. 
can discriminate low from high values; a RPD between 2 and 2.5 indicates that rough quantitative predictions are possible, and a RPD between 2.5 and 3 or above corresponds to good and excellent prediction accuracy (Nicolaï et al., 2007). Then, to illustrate the usefulness of the developed equations for the detection of subclinical ketosis, the percentage of data well-classified into 2 classes (low vs. high values) was calculated based on a threshold $0.15 \mathrm{mmol} / \mathrm{L}$ for acetone (de Roos et al., 2007), and the same classification was done with a threshold of $0.2 \mathrm{mmol} / \mathrm{L}$ for BHB (Denis-Robichaud et al., 2014). All computations and chemometric analysis were carried out with programs developed in Matlab v7.5.0. (The Mathworks Inc., Natick, MA) and the PLS toolbox v. 4.11 (Eigenvector Research Inc., Wenatchee, WA).

\section{RESULTS AND DISCUSSION}

\section{Reference Analysis}

Descriptive statistics of the initial data set are provided in Table 4. Content of BHB in the milk samples analyzed ranged from 0.045 to $1.595 \mathrm{mmol} / \mathrm{L}$ with an average of $0.215 \mathrm{mmol} / \mathrm{L}$ and a standard deviation of $0.174 \mathrm{mmol} / \mathrm{L}$. On average, BHB content was higher in the present data set than in the data set of de Roos et al. (2007; average of $0.146 \mathrm{mmol} / \mathrm{L}$ with value ranging from -0.021 to 3.960) and of Denis-Robichaud et al. (2014; average of $0.18 \mathrm{mmol} / \mathrm{L}$ with value ranging from -0.03 to $1.09 \mathrm{mmol} / \mathrm{L})$. Acetone content in the milk samples analyzed ranged from 0.020 to $3.355 \mathrm{mmol} / \mathrm{L}$ with an average of $0.103 \mathrm{mmol} / \mathrm{L}$ and a standard deviation of $0.260 \mathrm{mmol} / \mathrm{L}$. These values were in the same range than values presented by de Roos et al. (2007; from -0.021 to $3.960 \mathrm{mmol} / \mathrm{L}$ with an average of $0.146 \mathrm{mmol} / \mathrm{L}$ ) and by Denis-Robichaud et al. (2014; from -0.03 to 2.63 with an average of $0.100 \mathrm{mmol} / \mathrm{L}$ ). Citrate content in milk samples analyzed ranged from 3.88 to $16.12 \mathrm{mmol} / \mathrm{L}$ with an average of $9.04 \mathrm{mmol} / \mathrm{L}$ and a standard deviation of $2.21 \mathrm{mmol} / \mathrm{L}$. Calculated standard errors of the laboratory were respectively 0.005, 0.006, and $0.216 \mathrm{mmol} / \mathrm{L}$ for BHB, acetone, and citrate, meaning that the reference method was precise and did not affect the statistics obtained in the calibration step.
Considering their respective molar mass of 104.11, 58.08 , and $192.12 \mathrm{~g} / \mathrm{mol}$, these 3 molecules are present in milk on average at a level of $21.7 \mathrm{ppm}$ for BHB, $5.8 \mathrm{ppm}$ for acetone, and 1,684.31 ppm for citrate. Dardenne et al. (2015) mentioned that using FT-MIR technology, constituents cannot be detected below 100 ppm. Therefore, it is worth noting that calibration of BHB and acetone contents in milk cannot be done by the specific spectral response of these molecules in milk but by indirect links with global milk composition.

\section{BHB Cross-Validation and Validation Results}

After edits to obtain a more balanced data set between low and high values, the BHB data set contained 433 samples of which 325 samples were randomly included into the calibration data set. Because the best results were obtained using a log-transformation of the reference data, only these results are presented here. A PLS model was done using 8 latent variables, and 7 samples were considered as outliers and discarded. In the calibration data set, after removing the outliers, BHB content ranged from 0.045 to $1.595 \mathrm{mmol} / \mathrm{L}$ with an average of $0.235 \mathrm{mmol} / \mathrm{L}$ and a standard deviation of $0.193 \mathrm{mmol} / \mathrm{L}$. The average of predicted values is $0.219 \mathrm{mmol} / \mathrm{L}$, which is slightly smaller than the average of reference values; this is due to the slope between reference and predicted values of 1.1842 that can be observed in Figure 2A. Table 5 shows the cross-validation statistics. The RMSE of cross-validation obtained is $0.109 \mathrm{mmol} / \mathrm{L}$, with an $\mathrm{R}^{2}$ of cross-validation of 0.71 and a RPD of 1.77. The error is relatively high due to the lack of precision of the model on high values of the data set (Figure 2A), combined with the artificial removal of a series of samples with low values. The bias on high values might be induced by the logarithmic transformation of the reference data, giving more weight to low values in the model. However, when using a threshold of $0.200 \mathrm{mmol} / \mathrm{L}, 86.5 \%$ of the samples were well classified, with $87.4 \%$ of samples with low content of $\mathrm{BHB}$ and $85.0 \%$ of samples with high content of BHB well classified (Table 6), thereby demonstrating the usefulness of this equation to detect cows with an abnormally high content of BHB.

A data set of 108 samples was then used to perform an external validation. The BHB content ranged

Table 4. Descriptive statistics of the results from the reference analysis for BHB, acetone, and citrate

\begin{tabular}{llcccccc}
\hline Component & Unit & $\mathrm{N}$ & Minimum & Maximum & Mean & $\mathrm{SD}$ & SEL $^{1}$ \\
\hline BHB & $\mathrm{mmol} / \mathrm{L}$ & 558 & 0.045 & 1.596 & 0.215 & 0.174 & 0.005 \\
Acetone & $\mathrm{mmol} / \mathrm{L}$ & 548 & 0.020 & 3.355 & 0.103 & 0.260 & 0.006 \\
Citrate & $\mathrm{mmol} / \mathrm{L}$ & 506 & 3.88 & 16.12 & 9.04 & 2.21 & 0.216 \\
\hline
\end{tabular}

${ }^{1} \mathrm{SEL}=$ standard error of laboratory. 
(A)

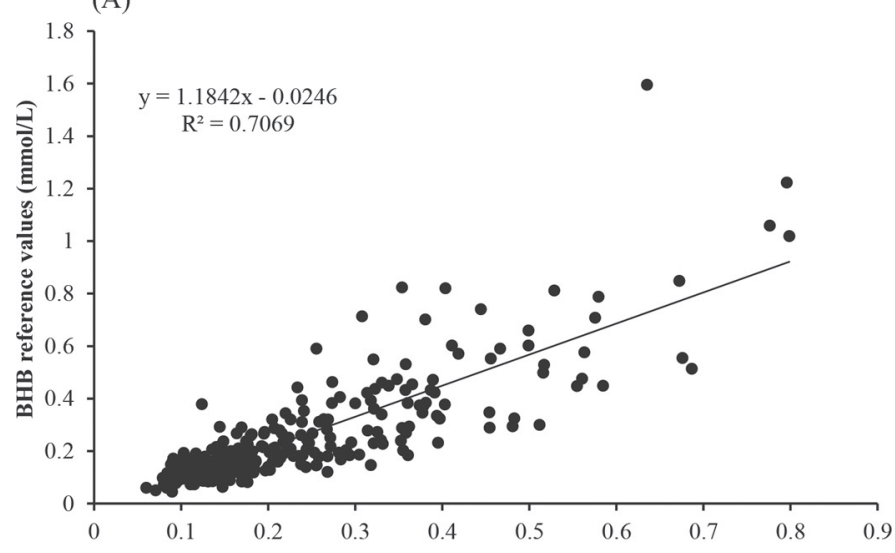

(B)

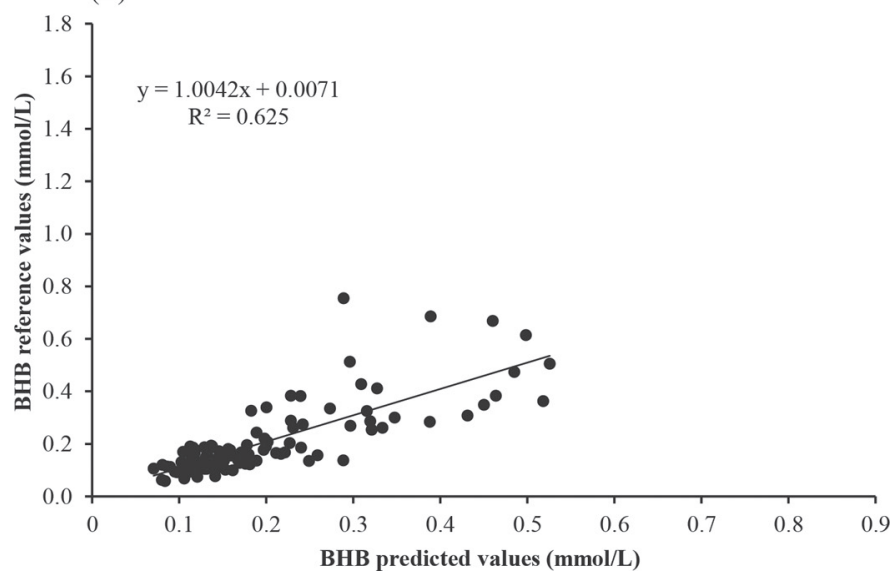

Figure 2. Plot of BHB reference values from flow injection analysis and BHB values predicted from Fourier transform mid-infrared analysis (A) for the cross-validation $(\mathrm{n}=325)$ and $(\mathrm{B})$ for the validation $(\mathrm{n}=108)$.

from 0.058 to $0.755 \mathrm{mmol} / \mathrm{L}$ with an average of 0.204 $\mathrm{mmol} / \mathrm{L}$ and a standard deviation of $0.136 \mathrm{mmol} / \mathrm{L}$ (Table 5). The average of predicted values, which is $0.198 \mathrm{mmol} / \mathrm{L}$, is comparable to the mean of reference values, showing a slope close to 1 between reference and predicted values in the validation step (Figure $2 \mathrm{~B}$ ). The RMSE of validation was $0.083 \mathrm{mmol} / \mathrm{L}$, with an $\mathrm{R}^{2}$ of 0.63 and a RPD of 2.33. The distribution of the data in the validation data set was slightly different than in the calibration data set, mainly due to reference values in average lower. Considering the lack of precision of the model for high values, this difference between the distribution of the calibration and validation data sets probably explained the difference in the cross-validation and validation statistics. The $\mathrm{R}^{2}$ highly depends on the distribution of the data and especially on the range of data (Davies and Fearn, 2006). The $\mathrm{R}^{2}$ of validation is lower than the $\mathrm{R}^{2}$ of cross-validation probably because of a reduced range of values (Figure 2B). However, the RMSE of validation is better, probably due to a higher proportion of samples with a relatively low content of BHB. Nevertheless, the accuracy shown by the model is satisfying and brings the RPD of validation higher than 2, which is the considered limit to start screening. Therefore, the equation developed in this study can provide an indicative value of the $\mathrm{BHB}$ content. When classifying the data of the validation data set into 2 classes by using a threshold of $0.200 \mathrm{mmol} / \mathrm{L}$, $90.8 \%$ of the samples were well classified, with $90.9 \%$ of samples with low BHB content and $90.6 \%$ of samples with high BHB content properly classified (Table 6). Therefore, one can conclude that the model is not good enough to provide precise quantitative values of milk $\mathrm{BHB}$, especially when BHB content is elevated, but it can allow discrimination between high and low values of BHB with an acceptable rate of good classification.

\section{Acetone Cross-Validation and Validation Results}

After edits to obtain a data set balanced between low and high values, the acetone data set contained 224 samples of which 168 samples that were randomly

Table 5. Cross-validation and validation statistics for BHB, acetone, and citrate contents in milk ${ }^{1}$

\begin{tabular}{|c|c|c|c|c|c|c|c|c|c|c|c|}
\hline Item & $\mathrm{N}$ & No. of LV & $\begin{array}{c}\text { No. of } \\
\text { outliers }\end{array}$ & Minimum & Maximum & Mean R & SD & Mean P & RMSE & $\mathrm{R}^{2}$ & $\mathrm{RPD}$ \\
\hline \multicolumn{12}{|l|}{$\mathrm{BHB}(\mathrm{mmol} / \mathrm{L})$} \\
\hline \multicolumn{12}{|l|}{ Acetone $(\mathrm{mmol} / \mathrm{L})$} \\
\hline Cross-validation & 168 & 7 & 2 & 0.020 & 3.355 & 0.190 & 0.397 & 0.146 & 0.248 & 0.73 & 1.60 \\
\hline \multicolumn{12}{|l|}{ Citrate (mmol/L) } \\
\hline Cross-validation & 380 & 9 & 2 & 3.88 & 16.12 & 9.03 & 2.26 & 9.02 & 0.70 & 0.90 & 3.21 \\
\hline Validation & 126 & - & - & 4.44 & 15.16 & 9.08 & 2.03 & 9.10 & 0.76 & 0.86 & 2.96 \\
\hline
\end{tabular}

${ }^{1}$ Number of samples used, number of latent variables (LV), descriptive statistics of the reference values [minimum, maximum, mean (mean $\mathrm{R}$ ), and $\mathrm{SD}]$, mean of the predicted values (mean P), root mean square error (RMSE), $\mathrm{R}^{2}$, and RPD (ratio SD of calibration/RMSE) are presented. 
Table 6. Results of classification of BHB predictions into 2 classes (\% of samples; using a threshold of 0.200 $\mathrm{mmol} / \mathrm{L}$ ) for cross-validation and validation data sets

\begin{tabular}{lccc}
\hline Item $(\%)$ & $\begin{array}{c}\text { Low BHB content } \\
(<0.200 \mathrm{mmol} / \mathrm{mL})\end{array}$ & $\begin{array}{c}\text { High BHB content } \\
(>0.200 \mathrm{mmol} / \mathrm{mL})\end{array}$ & $\begin{array}{c}\text { Global good } \\
\text { classification }\end{array}$ \\
\hline Cross-validation & $\mathrm{n}=198$ & $\mathrm{n}=120$ & $86.5 \%$ \\
Predicted low & $87.4 \%$ & $15.0 \%$ & \\
Predicted high & $12.6 \%$ & $85.0 \%$ & $90.8 \%$ \\
& $\mathrm{n}=32$ & \\
Validation & $90.9 \%$ & $9.4 \%$ & \\
Predicted low & $9.1 \%$ & $90.6 \%$ & \\
Predicted high & & & \\
\hline
\end{tabular}

selected and included in the calibration data set. The remaining 56 samples were included in the validation data set. In the calibration data set, acetone content ranged from 0.020 to $3.355 \mathrm{mmol} / \mathrm{L}$ with an average of $0.190 \mathrm{mmol} / \mathrm{L}$ and a standard deviation of 0.397 mmol/L. A PLS model was done using 7 latent variables, and 2 samples were considered as outliers. The average of predicted values is $0.146 \mathrm{mmol} / \mathrm{L}$; this highlights the slope effect of 1.6295 that can be observed in Figure $3 \mathrm{~A}$ between reference and predicted values. The RMSE of cross-validation was $0.248 \mathrm{mmol} / \mathrm{L}$, with an $\mathrm{R}^{2}$ of 0.73 and a RPD of 1.60 (Table 5). This RMSE was in a similar range to the one obtained by Hansen (1999) in cross-validation $(0.240 \mathrm{mmol} / \mathrm{L})$, by Heuer et al. (2001; $0.210 \mathrm{mmol} / \mathrm{L})$, and de Roos et al. (2007; $0.184 \mathrm{mmol} / \mathrm{L})$. Similarly to the BHB model, the acetone model was relatively imprecise when acetone values were high (Figure 3), and this lack of precision on high values affected dramatically the RMSE. However when classifying the data of the validation data set into 2 classes by using a threshold of $0.150 \mathrm{mmol} / \mathrm{L}, 93.4 \%$ of the samples were properly classified, with $95.5 \%$ of samples with low acetone content and $84.4 \%$ of samples with high acetone content well classified (Table 7).

In the validation data set, acetone content ranged from 0.021 to $1.968 \mathrm{mmol} / \mathrm{L}$ with an average of 0.179 $\mathrm{mmol} / \mathrm{L}$ and a standard deviation of $0.306 \mathrm{mmol} / \mathrm{L}$. The slope between reference and predicted values is confirmed in validation step with an average of predicted values of $0.145 \mathrm{mmol} / \mathrm{L}$ and a slope of 1.5033 (Figure $3 \mathrm{~B})$. The RMSE of validation was $0.196 \mathrm{mmol} / \mathrm{L}$, with an $\mathrm{R}^{2}$ of 0.67 and a RPD of 2.03 (Table 5). Even if the $\mathrm{R}^{2}$ was slightly lower in validation than in crossvalidation (0.67 instead of 0.73 ), the RMSE was also lower (0.196 instead of 0.248), meaning that the error was lower in the validation data set. Similarly than for $\mathrm{BHB}$, these results can be explained by the distribution of both validation and calibration data sets. The RMSE of validation is lower than the one obtained by Hansen (1999). In the latter study, the validation data set was constituted by samples from New Zealand, whereas the calibration data set included with samples collected in
Norway, Sweden, and Denmark. When classifying the data of the validation data set into 2 classes by using a threshold of $0.150 \mathrm{mmol} / \mathrm{L}, 89.3 \%$ of the samples were properly classified, with $93.0 \%$ of samples with low acetone content and $76.9 \%$ of samples with high acetone content well classified (Table 7). Therefore, similarly to the BHB model, the acetone model seems to be not

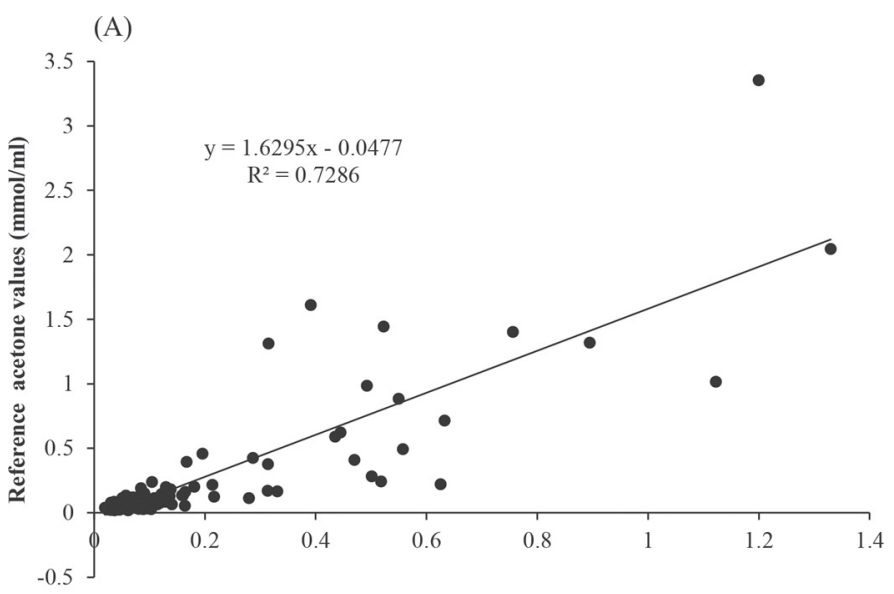

(B)

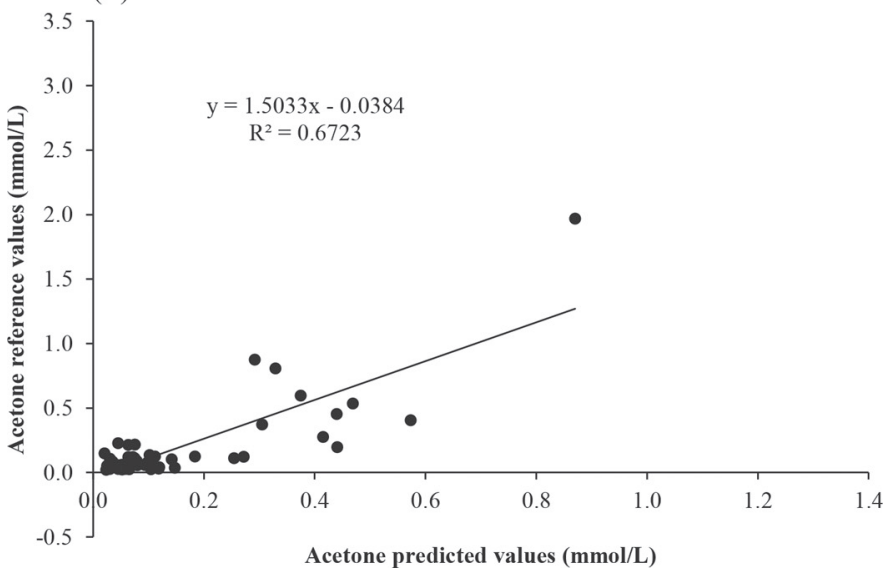

Figure 3. Plot of acetone reference values from flow injection analysis and acetone values predicted from Fourier transform mid-infrared analysis $(\mathrm{A})$ for the cross-validation $(\mathrm{n}=168)$ and $(\mathrm{B})$ for the validation $(\mathrm{n}=56)$. 
Table 7. Classification of the acetone predictions into 2 classes (\% of samples; using a threshold of 0.150 $\mathrm{mmol} / \mathrm{L}$ ) for cross-validation and validation data sets

\begin{tabular}{lccc}
\hline Item $(\%)$ & $\begin{array}{c}\text { Low acetone content } \\
(<0.150 \mathrm{mmol} / \mathrm{mL})\end{array}$ & $\begin{array}{c}\text { High acetone content } \\
(>0.150 \mathrm{mmol} / \mathrm{mL})\end{array}$ & $\begin{array}{c}\text { Global good } \\
\text { classification }\end{array}$ \\
\hline Cross-validation & $\mathrm{n}=134$ & $\mathrm{n}=32$ & $93.4 \%$ \\
Predicted low & $95.5 \%$ & $15.6 \%$ & \\
Predicted high & $4.5 \%$ & $\mathrm{n}=13$ & $89.3 \%$ \\
& $\mathrm{n}=43$ & $23.1 \%$ & \\
Validation & $93.0 \%$ & $76.9 \%$ & \\
Predicted low & $7.0 \%$ & Predicted high &
\end{tabular}

appropriate to provide precise quantitative values, especially when acetone content is elevated, but it can allow discriminating high from low acetone values.

\section{Citrate Cross-Validation and Validation Results}

The calibration data set for citrate contained 380 samples and the validation data set included 126 samples. In the calibration data set, citrate content ranged from 3.88 to $16.12 \mathrm{mmol} / \mathrm{L}$, with an average of $9.03 \mathrm{mmol} / \mathrm{L}$ and a standard deviation of $2.26 \mathrm{mmol} / \mathrm{L}$. The PLS model was done with 9 latent variables and 2 samples were considered as outliers. The slope between predicted and reference values is close to 1 (Figure 4) and the average of predicted values is comparable to the average of reference values, with respectively 9.03 and $9.02 \mathrm{mmol} / \mathrm{L}$. The RMSE of cross-validation obtained was $0.70 \mathrm{mmol} / \mathrm{L}$, which is very low compared with mean or standard deviation, leading to an RPD of 3.21 (Table 5), indicating a fair estimation of citrate content and the use of the model for screening (Williams, 2004). The $\mathrm{R}^{2}$ of cross-validation of the model was 0.90 (Figure $4 \mathrm{~A}$ ).

In the validation data set, the citrate content ranged from 4.44 to $15.16 \mathrm{mmol} / \mathrm{L}$, with an average of 9.08 $\mathrm{mmol} / \mathrm{L}$ and a standard deviation of $2.06 \mathrm{mmol} / \mathrm{L}$ (Table 5). The RMSE was $0.76 \mathrm{mmol} / \mathrm{L}$, and the $\mathrm{R}^{2}$ and the RPD were respectively 0.86 (Figure 4B) and 2.96. Hence, these results were satisfactory, thereby allowing the use of citrate as a potential novel biomarker in milk potentially useful for management and breeding of dairy cows.

\section{Implications}

Because standardized spectra were used in the development of the prediction equations for BHB, acetone, and citrate content in milk, these equations can be used on all standardized instruments from the OptiMIR network (Grelet et al., 2015), thereby allowing the utilization of these new biomarkers in the development of breeding and management tools for dairy cows. Hence, the equations developed in the frame of this project have been disseminated throughout the OptiMIR network. In laboratories, the spectra are extracted from the instruments, stored into external database, and standardized before application of the equations. With automation and IT development, these steps can be run daily, producing a quick feedback on field. Taking into

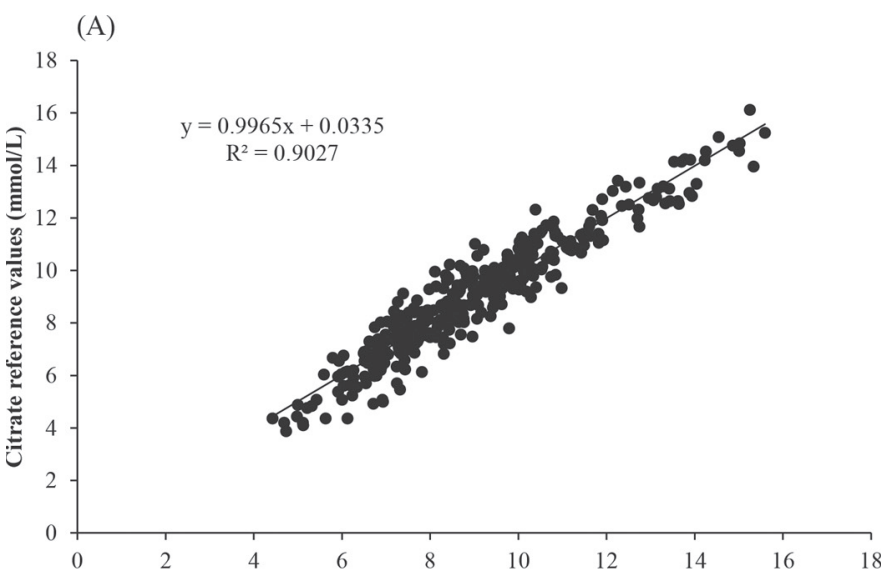

(B)

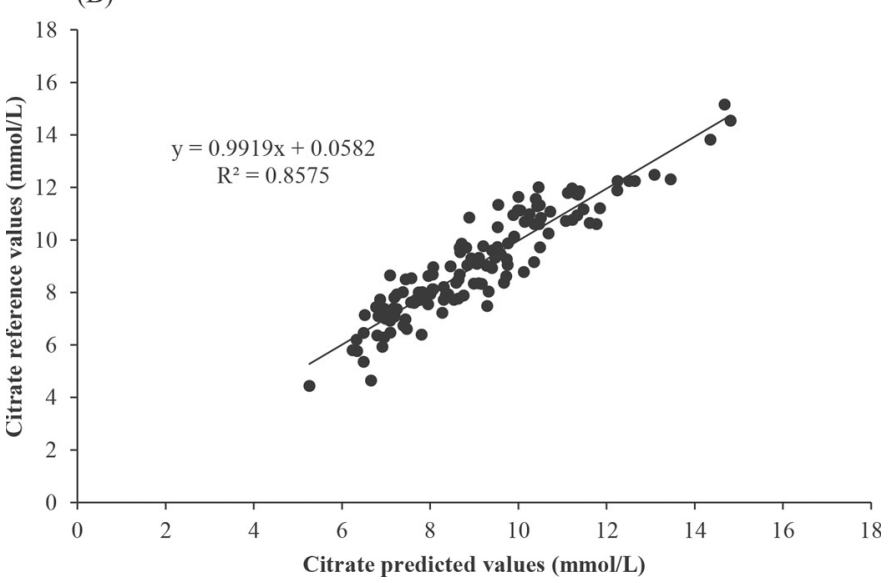

Figure 4. Plot of citrate reference values from flow injection analysis and citrate values predicted from Fourier transform mid-infrared analysis (A) for the cross-validation $(\mathrm{n}=380)$ and $(\mathrm{B})$ for the validation $(\mathrm{n}=126)$. 
account the precision of the different calibrations, the predictions could be used for herd management, or at individual level by using thresholds or relative values to cope with low accuracy. In 2015, advisory tools for the detection of cows potentially suffering from (sub-)clinical ketosis or from energy deficit have been deployed in Alsace region in France (Pezon, 2015) and in Luxembourg and are still under development in Germany, United Kingdom, and the Walloon Region of Belgium (Baugnies, 2015). Further studies will investigate the opportunity of using these traits as indicators of health traits and fertility in breeding programs.

\section{CONCLUSIONS}

This work confirmed the usefulness of the FT-MIR spectrometry to predict milk biomarkers such as the content in milk of acetone, BHB, and citrate. Cross-validation statistics of the developed equations for acetone and BHB were similar or better than previous work and highlighted the opportunity to use these predictions for the detection of cows with high or low levels of ketone bodies in milk rather than for the determination of their exact content. Such results are expected given that the low concentration of BHB and acetone in milk implies only an indirect calibration of these components. Additionally, external validation statistics were provided in this work and confirmed the cross-validation results. Although further research is warranted to demonstrate the interest of mid-infrared predicted citrate as a useful biomarker for the dairy industry, this study showed that the development of FT-MIR calibration for citrate content in milk is promising. Finally, this work emphasized the usefulness of the standardization of mid-infrared spectra from different FT-MIR spectrophotometers to merge data sets and create more robust calibrations that can be used through a large network.

\section{ACKNOWLEDGMENTS}

The authors gratefully acknowledge the laboratories and experimental farms providing data for this work: Comité du lait de Battice (Belgium), MPR-Kirchheim (Germany), ANALIS 53 (France), Trinottières experimental farm (France), Marcenat experimental farm (France), and Neumühle experimental farm (Germany). The National Fund for Scientific Research (FNRS, Brussels, Belgium) is acknowledged for grant agreement project 2.4604.11 (COMPOMILK project). The authors also thank the INTERREG IVB NWE program and the Ministry of Agriculture of Walloon Region of Belgium (Service Public de Wallonie, Direction générale opérationnelle "Agriculture, Ressources naturelles et Environnement"; DGARNE) for their financial support to the OptiMIR project (www.optimir.eu). Nicolas Gengler, as a former senior research associate, also acknowledges the support of the FNRS. The authors acknowledge especially Claire Darimont (CRA-W, Gembloux, Belgium) for her valuable work on chemical analysis.

\section{REFERENCES}

Baticz, O., S. Tömösközi, L. Vida, and T. Gaál. 2002. Relationship between concentration of citrate and ketone bodies in cow's milk. Acta Vet. Hung. 50:253-261. http://dx.doi.org/10.1556/ AVet.50.2002.3.1.

Baugnies, S. 2015. Mise au point d'un indicateur de défaut énergétique des vaches à partir de nouvelles molécules disponibles via l'analyse spectrale du Contrôle Laitier dans le cadre du projet européen OptiMIR. Ms Thesis. Haute Ecole Condorcet, Prov. Hainaut, Belgium.

Bjerre-Harpøth, V., N. C. Friggens, V. M. Thorup, T. Larsen, B. M. Damgaard, K. L. Ingvartsen, and K. M. Moyes. 2012. Metabolic and production profiles of dairy cows in response to decreased nutrient density to increase physiological imbalance at different stages of lactation. J. Dairy Sci. 95:2362-2380. http://dx.doi. org/10.3168/jds.2011-4419.

Bonfatti, V., G. Di Martino, and P. Carnier. 2011. Effectiveness of mid-infrared spectroscopy for the prediction of detailed protein composition and contents of protein genetic variants of individual milk of Simmental cows. J. Dairy Sci. 94:5776-5785. http://dx.doi. org/10.3168/jds.2011-4401.

Butler, W. R. 2003. Energy balance relationships with follicular development, ovulation and fertility in postpartum dairy cows. Livest. Prod. Sci. 83:211-218. http://dx.doi.org/10.1016/S03016226(03)00112-X.

Collard, B. L., P. J. Boettcher, J. C. Dekkers, D. Petitclerc, and L. R. Schaeffer. 2000. Relationships between energy balance and health traits of dairy cattle in early lactation. J. Dairy Sci. 83:2683-2690. http://dx.doi.org/10.3168/jds.S0022-0302(00)75162-9.

Dardenne, P., J. A. Fernandez Pierna, O. Abbas, V. Baeten, and B. Lecler. 2015, Untargeted multivariate characterization of contaminants in powdered milk. Proc. Final Optimir Scientific and Expert Meeting: From Milk Analysis to Advisory Tools. Namur (Belgium), 16-17 April 2015, BASE, vol. 19(2).

Davies, A., and T. Fearn. 2006. Back to basics: Calibration statistics. Spectroscopy Europe 18:31-32.

De Marchi, M., V. Toffanin, M. Cassandro, and M. Penasa. 2014. Invited review: Mid-infrared spectroscopy as phenotyping tool for milk traits. J. Dairy Sci. 97:1171-1186. http://dx.doi.org/10.3168/ jds.2013-6799.

de Roos, A. P. W., H. J. C. M. van den Bijgaart, J. Hørlyk, and G. de Jong. 2007. Screening for subclinical ketosis in dairy cattle by Fourier transform infrared spectrometry. J. Dairy Sci. 90:1761-1766. http://dx.doi.org/10.3168/jds.2006-203.

Denis-Robichaud, J., J. Dubuc, D. Lefebvre, and L. DesCôteaux. 2014 Accuracy of milk ketone bodies from flow-injection analysis for the diagnosis of hyperketonemia in dairy cows. J. Dairy Sci. 97:33643370. http://dx.doi.org/10.3168/jds.2013-6744.

Duffield, T. 2000. Subclinical ketosis in lactating dairy cattle. Vet. Clin. North Am. Food Anim. Pract. 16:231-253.

Enjalbert, F., M. C. Nicot, C. Bayourthe, and R. Moncoulon. 2001. Ketone bodies in milk and blood of dairy cows: Relationship between concentrations and utilization for detection of subclinical ketosis. J. Dairy Sci. 84:583-589. http://dx.doi.org/10.3168/jds. S0022-0302(01)74511-0.

Gengler, N., H. Soyeurt, F. Dehareng, C. Bastin, F. G. Colinet, H. Hammami, and P. Dardenne. 2015. Overview of possibilities and challenges of the use of infrared spectrometry in cattle breeding, Page 353 in Proc. EAAP 66th Annual Meeting, Warsaw. Wageningen Academic Publishers, Wageningen, the Netherlands. 
Gengler, N., H. Soyeurt, F. Dehareng, C. Bastin, F. G. Colinet, H. Hammami, M. L. Vanrobays, A. Lainé, S. Vanderick, C. Grelet, A. Vanlierde, E. Froidmont, and P. Dardenne. 2016. Capitalizing on fine milk composition for breeding and management of dairy cows. J. Dairy Sci. 99:1-9. http://dx.doi.org/10.3168/jds.2015-10140.

Grelet, C., J. A. Fernández Pierna, P. Dardenne, V. Baeten, and F. Dehareng. 2015. Standardization of milk mid-infrared spectra from a European dairy network. J. Dairy Sci. 98:2150-2160. http:// dx.doi.org/10.3168/jds.2014-8764.

Hansen, P. W. 1999. Screening of dairy cows for ketosis by use of infrared spectroscopy and multivariate calibration. J. Dairy Sci. 82:20052010. http://dx.doi.org/10.3168/jds.S0022-0302(99)75437-8.

Hanuš, O., V. Genčurová, Y. Zhang, P. Hering, J. Kopecký, R. Jedelská, A. Dolínková, and Z. Motyčka. 2011. Milk acetone determination by the photometrical method after microdiffusion and via FT infra-red spectroscopy. J. Agrobiol. 28:33-48.

Hanuš, O., P. Roubal, J. Ř́ha1, M.Y. Klimešová, E. Samková, R. Jedelská, and J. Kopecký. 2014. Development in indirect infra-red determination of milk acetone. Acta Univ. Agric. Silvic. Mendel. Brun. 62:919-927.

Heuer, C., H. J. Luinge, E. T. Lutz, Y. H. Schukken, J. H. van der Maas, H. Wilmink, and J. P. Noordhuizen. 2001. Determination of acetone in cow milk by Fourier transform infrared spectroscopy for the detection of subclinical ketosis. J. Dairy Sci. 84:575-582. http://dx.doi.org/10.3168/jds.S0022-0302(01)74510-9.

Lainé, A., H. Bel Mabrouk, L. M. Dale, C. Bastin, and N. Gengler. 2014. How to use mid-infrared spectral information from milk recording system to detect the pregnancy status of dairy cows. Commun. Agric. Appl. Biol. Sci. 79:33-38.

McParland, S., G. Banos, E. Wall, M. P. Coffey, H. Soyeurt, R. F. Veerkamp, and D. P. Berry. 2011. The use of mid-infrared spectrometry to predict body energy status of Holstein cows. J. Dairy Sci. 94:3651-3661. http://dx.doi.org/10.3168/jds.2010-3965.

McParland, S., E. Lewis, E. Kennedy, S. G. Moore, B. McCarthy, M. O'Donovan, S. T. Butler, J. E. Pryce, and D. P. Berry. 2014. Mid-infrared spectrometry of milk as a predictor of energy intake and efficiency in lactating dairy cows. J. Dairy Sci. 97:5863-5871. http://dx.doi.org/10.3168/jds.2014-8214.

Nicolaï, B. M., K. Beullensa, E. Bobelyna, A. Peirs, W. Saeys, K. I. Theronb, and J. Lammertyn. 2007. 2007, Nondestructive measurement of fruit and vegetable quality by means of NIR spectroscopy: A review. Postharvest Biol. Technol. 46:99-118.

Pezon, J. 2015. La cétose subclinique détectée par le spectre MIR. L'éleveur Laitier 234:48-51.

Rousseeuw, P. J., M. Debruyne, S. Engelen, and M. Hubert. 2006. Robustness and outlier detection in chemometrics. Crit. Rev. Anal. Chem. 36:221-242.

Rutten, M. J. M., H. Bovenhuis, K. A. Hettinga, H. J. F. van Valenberg, and J. A. M. van Arendonk. 2009. Predicting bovine milk fat composition using infrared spectroscopy based on milk samples collected in winter and summer. J. Dairy Sci. 92:6202-6209. http://dx.doi.org/10.3168/jds.2009-2456.

Soyeurt, H., C. Bastin, F. G. Colinet, V. M.-R. Arnould, D. P. Berry, E. Wall, F. Dehareng, H. N. Nguyen, P. Dardenne, J. Schefers, J. Vandenplas, K. Weigel, M. Coffey, L. Théron, J. Detilleux, E. Reding, N. Gengler, and S. McParland. 2012. Mid-infrared prediction of lactoferrin content in bovine milk: potential indicator of mastitis. Animal 6:1830-1838. http://dx.doi.org/10.1017/ S1751731112000791.

Soyeurt, H., D. Bruwier, J.-M. Romnee, N. Gengler, C. Bertozzi, D. Veselko, and P. Dardenne. 2009. Potential estimation of major mineral contents in cow milk using mid-infrared spectrometry. J. Dairy Sci. 92:2444-2454. http://dx.doi.org/10.3168/jds.2008-1734.

Soyeurt, H., F. Dehareng, N. Gengler, S. McParland, E. Wall, D. P. Berry, M. Coffey, and P. Dardenne. 2011. Mid-infrared prediction of bovine milk fatty acids across multiple breeds, production systems, and countries. J. Dairy Sci. 94:1657-1667. http://dx.doi. org $/ 10.3168 /$ jds.2010-3408.

Suthar, V. S. J. Canelas-Raposo, A. Deniz, and W. Heuwieser. 2013. Prevalence of subclinical ketosis and relationships with postpartum diseases in European dairy cows. J. Dairy Sci. 96:2925-2938. http://dx.doi.org/10.3168/jds.2012-6035.

van der Drift, S. G., K. J. E. van Hulzen, T. G. Teweldemedhn, R. Jorritsma, M. Nielen, and H. C. M. Heuven. 2012. Genetic and nongenetic variation in plasma and milk $\beta$-hydroxybutyrate and milk acetone concentrations of early-lactation dairy cows. J. Dairy Sci. 95:6781-6787. http://dx.doi.org/10.3168/jds.2012-5640.

van Knegsel, A. T., S. G. A. van der Drift, M. Horneman, A. P. W. de Roos, B. Kemp, and E. A. M. Graat. 2010. Short communication: Ketone body concentration in milk determined by Fourier transform infrared spectroscopy: Value for the detection of hyperketonemia in dairy cows. J. Dairy Sci. 93:3065-3069. http://dx.doi. org/10.3168/jds.2009-2847.

Vanlierde, A., M.-L. Vanrobays, F. Dehareng, E. Froidmont, H. Soyeurt, S. McParland, E. Lewis, M. H. Deighton, F. Grandl, M. Kreuzer, B. Gredler, P. Dardenne, and N. Gengler. 2015. Hot topic: Innovative lactation-stage-dependent prediction of methane emissions from milk mid-infrared spectra. J. Dairy Sci. 98:57405747. http://dx.doi.org/10.3168/jds.2014-8436.

Williams, P. C. 2004. Variables affecting near-infrared reflectance spectroscopic analysis. Pages 145-169 in Near Infrared Technology in the Agriculture and Food Industries. 2nd ed. P. Williams and K. Norris, ed. Am. Cereal Assoc. Cereal Chem., St. Paul, MN.

Williams, P. C., and D. C. Sobering. 1993. Comparison of commercial near infrared transmittance and reflectance instruments for analysis of whole grains and seeds. J. Near Infrared Spectrosc. 1:25-32. 